\title{
ANALYSIS OF THE EFFECT OF ONLINE SHOPPING VALUE, EFFECTIVENESS OF INFORMATION CONTENT ON PURCHASE INTENTION WITH WEB SATISFACTION AS MEDIATION ON MILLENNIALS IN BATAM CITY
}

\author{
Lily Purwianti ${ }^{1)}$, Felby Jeslyn ${ }^{2)}$ \\ ${ }^{1,2)}$ Universitas Internasional Batam, Riau Islands, Indonesia \\ Corresponding author: lily.purwianti@uib.ac.id
}

\begin{abstract}
The development of e-commerce with the C2C category is very fast and is dominated by the millennial generation. The millennial generation is a generation that was born in modern and technologically advanced conditions. Therefore, it is necessary to research. This investigation was conducted to determine whether online buying values also the effectiveness of information content affect Web Satisfaction and will affect millennial buying intentions in Batam city. Data samples in this study were carried out by distributing questionnaires to 350 data and treated by SmartPLS. The outcomes of this investigation state that hedonic shopping value, utilitarian shopping value, the effectiveness of information content affect purchase intention, also Satisfaction as a mediation between hedonic shopping value, utilitarian shopping value, the effectiveness of information content, also purchase intention.
\end{abstract}

Keywords: Hedonic Shopping Value, Utilitarian Shopping Value, The Effectiveness Of Information Content, Purchase Intention

\section{Introduction}

The high level of economic growth and increasing human needs have resulted in various industries being created to meet human needs. Along with the times, the demand for human needs is increasingly modern, practical, and quality, so that many technologies are designed to meet human needs. Technology functions as a means to provide all the goods needed by humans to realize the prosperity and welfare of society. One proof of the rapid development of technology is the internet. The internet is an interconnection of computer networks that can provide complete information. (Sidharta, 2014).

In 2018 Indonesia recorded 132 million people using the internet, or more than $50 \%$ of Indonesians have used the internet. Of these million users, $60 \%$ percent have accessed the internet using smartphones. This proves that Indonesia has begun to follow the steps of technological development. Based on a survey of internet usage by gender, men with $51.43 \%$ and women $48.57 \%$. (Liputan6,2018). In 2018, Indonesia was recorded as an internet user at $17 \%$ at the age of $13-18$ years, $49 \%$ at the age of $19-34$ years, $30 \%$ at the age of 35-54 years, and 4\% at the age above 54 years. (Kompas.com, 2018). This proves that the highest percentage of internet users is 19-34 years old.

According to Ali and Purwandi (2017), millennials are born between 1981 and 2000, while other domestic social researchers use birth years from 1980 to 2000 to identify millennials (Knowing Millennial Generation, Sindonews.com, 2015). The definition of millennial depends on experts from various countries and industries; the generation born in 1980 to 2000 is referred to as the millennium generation. That means that millennials are often used as an abbreviation for young people, and the oldest members of the group are now in their late 30s (metalfloss.com, 2018). U.S. Pirg Institute defines where people were born in a world of modern conditions also sophisticated technology, so it's no surprise that the highest rate of internet users are millennials.

In 2018 a survey proved that $64 \%$ of online marketplace consumers came from the age group of 25-30 years (jakartaglobel.id, 2018). Based on these data, it can be concluded that most millennials cannot be separated from gadgets due to the generation factor born when technology was developing so that the internet can affect the survival of millennials (tribunews.com, 2019). Technological developments certainly influence the marketing field or known as e-commerce today, and e-commerce is known as an actor in the sale and purchase transaction of goods along with digital services. One type of e-commerce platform that is common in Indonesia is $\mathrm{C} 2 \mathrm{C}$ (Customer to Customer). $\mathrm{C} 2 \mathrm{C}$ is a type of e-commerce that facilitates consumers of the e-commerce company, namely consumers as sellers and buyers. $\mathrm{C} 2 \mathrm{C}$ is also a marketplace where ecommerce companies are involved in securing transactions from ordering, shipping to payment. Marketplaces categorized in $\mathrm{C} 2 \mathrm{C}$ are: Bukalapak, Jualo.com, Shopee, and Tokopedia. (trendingbisnis.com, 2019).

In 2019, the most visited C2C marketplaces were Tokopedia, Shopee, and Bukalapak, so it can be concluded that to date, the three most frequently visited C2C marketplaces are Tokopedia, Shopee, and Bukalapak. One of the factors supporting the development of e-commerce today is the website, and now the website is an essential part of the success of e-commerce, the perfection of the website from e-commerce will greatly support business development wherefrom the website customers can find the information needed and 
can find out more about marketplaces. Information defines meaning and benefits from processing data (Azhar, 2013). (Chang et al., 2014) Chang et al., 2014) additionally demonstrated that a "website" that makes high levels of shoppers would change shopper decision making because the most significant shoppers believe that a famous website is more likely to fulfill their needs.

Buying interest can arise because of the satisfaction factor for a product or because it is caused by pleasure (hedonic shopping value) and one's need for the product (utilitarian shopping value). Electronic shoppers prefer online stores with an excellent web atmosphere, eye-catching graphics, attractive designs, and website layouts. (Prashar et al., 2017) where entertainment is an essential component of shopping (Triantafillidou et al., 2017), given that users communicate through their device interfaces, designing, including developing efficient mobile interfaces, is an essential determinant of e-commerce penetration plus growth.

Online buyers tend to use web portals to explore information and buy goods/services by spending little time, including effort. Precise, relevant, and up-to-date information provided by web portals will reduce the time and energy of shoppers to search for information, which in turn helps them have a pleasant experience (Kim \& Li, 2009). The quality of information can be considered adequate if the information can meet the needs of its users and can produce the maximum possible output. It can be concluded that a good quality website will increasingly meet user needs and if customer needs are met they tend to be satisfied with the web and purchase intention tends to increase. With this background, they conducted research entitled "Analysis of the Effect of Online Shopping Value, Effectiveness Of Information Content on Purchase Intention with Web Satisfaction as Mediation on Millennials in Batam City."

\section{Literature Review}

The level of customer purchase intention can be measured from several indicators, namely the customer's willingness to shop for the product, the customer's desire to make purchases in the future, and the customer's willingness to repurchase the product. The desire to shop can arise because of the satisfaction factor for a product or cause by pleasure and one's needs for development. Electronic shoppers prefer online stores with a unique web atmosphere, eye-catching graphics, attractive designs, and website layouts. Prashar et al., (2017). Online shoppers tend to use web portals to access information when buying goods/services because it requires less time and effort. Users based on satisfaction are higher and often have stronger intentions in purchasing through trading sites. (Gan \& Wang, 2017).

Purchase intention is an important outcome variable. During the initial visit to the website, the service provider faces the main challenge of converting visitors into buyers, and purchase intention directly affects the company's revenue and profitability (Hsu et al., 2012). From a customer perspective, online shopping is a core part of e-commerce. Customers buy products, search for information and services from online websites, and form purchasing activities: purchase, activity, post-purchase activity, pre-purchase (Cao et al., 2018). Purchase intention can be interpreted as a customer's intention to buy a specific item, in the same way that the desire to buy determines the strength of the consumer's willingness to accept. It is essential to know the customer's purchase intention because the buyer's intention often predicts the customer's behavior.

\section{The Effect of Hedonic Shopping Value and WebSatisfaction}

Hedonic values are related to non-functioning (e.g., self-fulfillment) on the origin of social trading sites, such as enjoyment and happiness, and more attention to emotional benefits. (Hsu \& Lin, 2016). Consumers are more interested in emotional value (e.g., brand, design, appearance, and packaging). Consumers will feel satisfied if the product purchased can meet the needs in terms of pleasure, so it can be concluded that a product that can satisfy consumers who are judged in terms of fun can increase consumer buying interest.

Hedonic motivation is related to the pleasurable and pleasurable emotional experience provided by the act of buying. Hedonic value is defined as an assessment of customer acceptance based on the multisensory and emotional aspects of the shopping experience. Users who get a higher hedonic value through a pleasant experience are more willing to have different individual experiences and encourage friends and family to use this service (Yu et al., 2013). Hedonic value can come from positive, fun, and entertaining experiences (including in online environments), and hedonic processes are often accompanied by elements or feelings of fantasy, fun, excitement, and spontaneity. Emotional arousal, high involvement, perceived freedom, and realization of story and escape symbolize the hedonic value of shopping. During a shopping trip, consumers can get hedonic benefits and experience hedonic value even when they don't buy any product, so even if shopping doesn't result in an actual purchase, hedonic value can still be obtained from many aspects of the shopping process, one of which is making the shopping trip an adventure. (Lee \& Wu, 2017). Previous studies that concluded that there was an influence between Hedonic Shopping Value on Satisfaction were Gan and Wang (2017); Hsu and Lin (2016); Yu et al. (2013); Lee and Wu (2017); Kesari and Atulkar (2016).

\section{The Influence of Utilitarian Shopping Value and Web Satisfaction}

Utilitarian value refers to the key features and benefits provided through social commerce sites, such as cost reduction and convenience, with a focus on consumer views of performance and utility (Gan \& Wang, 2017). Consumers with utilitarian behavior patterns tend to choose products based on rational reasons. The 
practical value indicates that toward customers in complex buying conditions, the discovery of essential products, including services, gives the insight from value, somewhat than treating buying as an entertaining pastime.

Utilitarian value means a consumer's overall assessment of a product or service's practical advantages including weaknesses. Customer functional style should be represented as task-oriented also rational, and the utilitarian value depends on spending as an internal working state, also that perceived practical value is defined by whether a task-specific buying incited by customer demand has been completed; therefore, utilitarian customers seek the most effective approach toward making buying activities (Lee \& Wu, 2017). Consumers will feel a high level of control over the material system of online purchasing situations, which allows them to take the desired part of the information directly or leap the advertisement and go now to the purchasing procedure, thereby speeding up the completion of the consumer's purchasing task. Utilitarian values are related to the task-specific, efficient, and economic aspects of a product or service. Functional values incorporate cognitive elements of attitudes, such as economic value for money and judgments of convenience and time-saving. Convenience and task fulfillment are the main goals of consumers to use cellular services (Cao et al., 2018).

Utilitarian value derives from the instrumental and functional benefits of the product's task-specific, efficient, and economic aspects or services. Practical matters incorporate cognitive elements of attitudes, such as economic value for money and convenience, and time savings (Yu et al., 2013). Previous studies which state that there is an influence between Utilitarian Shopping Value on Satisfaction are Lee and Wu (2017); Gan and Wang (2017); Yu et al. (2013); Kesari and Atulkar (2016); Hsu and Lin (2016).

\section{Effect of Effectiveness of Information Content and Web Satisfaction}

According to Prashar et al. (2017), the effectiveness of information content can be used to determine whether the information provided by the website is correct, up-to-date, complete, and pertinent to the buyer. Set. The quality of data can be judged from adequate (information can meet its users), efficient (information can produce the maximum possible output), economical (the economic system is economically feasible), and computerized system (system application).

The internet contributes several facilities to communication. Interactivity refers to the synergy between the site and the site user that goes to the core of the computer-mediated information conditions, including human-human synergy and human-message communication, operationally described as the degree to which two-way connection among readers is promoted, including the availability plus effectiveness of interaction on the website. Interactivity has the potential to be an important influence in creating online links so that the information provided by websites must be tailored based on consumer needs (Ho \& Lee, 2016).

The information consumers are looking for varies, including information about services, discounts, and customer service. Another aspect to consider related to website design is that it must be well structured and organized; there is a difference between graphic quality and design clarity (Ahmad et al., 2017). The first is to visually represent various user interface elements (text, icons, images). digital or website background) and the latter is defined as the structural design of user interfaces that help customers find the information they need. Website structure and ease of use can reduce customer costs in information search and processing and reduce time spent on purchases. The more effective the information provided from the website, the more likely the consumer's purchase intention will also increase. The results of the study that concluded that the Effectiveness of information content affected Web Satisfaction were Wong et al. (2016); Prashar et al. (2017); Wang et al., (2014) Ladhari and Leclerc, (2013). According to Ahmad et al. (2017), the research results do not say so because the results of their research state that Information Quality has no significant effect on Web Satisfaction.

\section{Effect of Web Satisfaction and Purchase Intention}

Satisfaction is the central construct for evaluating product/service performance; in addition, satisfaction has been found to affect loyalty, purchase intention, and outcomes most critically in a retail context (Elmashhara \& Soares, 2019). Satisfaction is an internal and relational determinant of trust in perceptions of opportunism. Customers Satisfied are willing to return a store and help promote positively if customers feel high satisfaction by a website, the probability of their unplanned shopping. Satisfaction can lead to positive attitudes towards the organization and supportive behavioral intentions. The positive effect of satisfaction on shopping intentions involved in positive WOM and relationship quality can lead to repeat purchases and recommendations (positive WOM). Satisfaction is represented as a user's evaluation of social trading based on their needs and expectations, referring to the user's positive emotional state obtained from using the service (Gan \& Wang, 2017). Satisfaction is the key to strengthening relationships in e-commerce. Customer service has been carried out extensively to obtain more varied aspects of salesperson service in the selection and support of goods, troubleshooting, and answers to usually asked issues via email also other plans, distribution of required information, and settlement of payments and credit transactions. Cao et al. (2018) concluded that the perception of shopper service quality has a meaningful influence on satisfaction, influencing customers' prospective purchase purposes. 
There are several critical activities for an e-commerce organization to ensure a company's success in the market. Those include preparation in reacting to customer requests in complaints, access to services, also perceptions of the quality of service received. The better the quality of the website, the more it will meet the needs of users, and if customer needs are met, they tend to be satisfied with the web, and purchase intentions tend to increase. Previous studies that concluded Web Satisfaction with its effect on Purchase Intention are Gan and Wang (2017); Hsu and Lin (2016); Papagiannidis et al. (2017); Cao et al. (2018); Hsu et al., (2012).

From the literature review above, the research hypotheses are:

H1: Hedonic Shopping Value has a significant effect on Web Satisfaction.

H2: Utilitarian Shopping Value has a substantial impact on Web Satisfaction.

H3: Effectiveness of information content has a substantial impact on Web Satisfaction.

H4: Hedonic Shopping Value significantly affects Purchase Intention with Web Satisfaction mediation.

H6: Utilitarian Shopping Value significantly affects Purchase Intention to mediate Web Satisfaction.

H7: Web Satisfaction has a significant effect on Purchase Intention.

\section{Research Methods}

The research population is taken by researchers, namely people who know about websites and have accessed them in online shopping. The samples used by researchers in this study are millennials who know and have accessed C2C marketplace websites (tokopedia, shopee, and Bukalapak) in purchasing goods. in the city of Batam. Researchers chose millennials because in 2018 the survey proved that $64 \%$ of online marketplace consumers were dominated by the millennial generation (jakartaglobel.id, 2018), and the websites that the researchers chose in this study were Tokopedia, Shopee, and Bukalapak, wherein 2018 they were the top three most visited marketplace (price. insights, 2018). The number of samples used by the author in this study is by observing the parameter 1 to 10 (Hair et al., 2014), namely the comparison between the statement and the number of respondents. In this study, there are 24 questions, and each question will be represented by 10 respondents, so the minimum number of respondents in this study is 300 people.

The sample selection method uses "nonprobability" sampling; the technique used in this study is "purposive sampling," which is taking samples from people with particular criteria that have been determined by the researcher. The requirements are respondents in the age group "19-39 years" who have accessed ecommerce websites (tokopedia, Shopee, and Bukalapak) in purchasing goods in the city of Batam. The analysis in this study is personal because what will be observed are people who have shopped online using a website in the city of Batam. The purchase intention variable uses 4 statements, Web satisfaction uses 3 accounts from (Prashar et al., 2017). Hedonic Shopping Value uses three statements from Mosunmola et al., 2019, Utilitarian shopping value uses 6 reports from Mosunmola et al., 2019; informativeness web uses four statements, Effectiveness of information content uses 4 statements from (Prashar et al., 2017). The measurement scale uses a 5-point Likert scale.

\section{Result and Discussion Validity Test and Reliability Test}

The results of the validity test state that all variable indicators are valid because their values are above 0.5, namely Effectiveness of Information Content (0.670), Hedonic Shopping Value (0.657), Utilitarian Shopping Value (0.506), Purchase Intention (0.733), Satisfaction (0.700). Reliability test results also all variables are reliable because the value is above 0.5, namely Effectiveness of Information Content (0.878), Hedonic Shopping Value (0.739), Utilitarian Shopping Value (0.758), Purchase Intention (0.878), Satisfaction (0.785).

\section{Hypothesis Testing}

A variable can have a significant effect if it has a substantial value at $5 \%, \mathrm{P}$-value $<0.05$, and $\mathrm{T}$ statistic value $>1.96$ (Hair et al., 2011). The following table shows that all hypotheses are accepted.

Table 1. Hypothesis Testing

\begin{tabular}{lccc}
\hline \multicolumn{1}{c}{ Hypothesis } & T-statistic & P-Value & Conclusion \\
\hline Hedonic Shopping value $\rightarrow$ Satisfaction & 4.519 & 0,000 & H1: Significantly Positive \\
\hline $\begin{array}{l}\text { Utilitarian Shopping Value } \rightarrow \text { Satisfaction } \\
\begin{array}{l}\text { Effectiveness of Information Content } \rightarrow \\
\text { Satisfaction }\end{array}\end{array}$ & 3.927 & 0,000 & H2: Significantly Positive \\
\hline $\begin{array}{l}\text { Hedonic Shopping } \\
\text { value } \rightarrow \text { Satisfaction } \rightarrow \text { Purchase Intention }\end{array}$ & 4.230 & 0,000 & H4: Significantly Positive \\
\hline $\begin{array}{l}\text { Utilitarian Shopping Value } \rightarrow \text { Satisfaction } \rightarrow \\
\text { Purchase Intention }\end{array}$ & 3.700 & 0,000 & H5: Significantly Positive \\
$\begin{array}{l}\text { Effectiveness of Information Content } \\
\rightarrow \text { Satisfaction } \rightarrow \text { Purchase Intention }\end{array}$ & 6.002 & 0,000 & H6: Significantly Positive \\
\hline
\end{tabular}




Satisfaction $\rightarrow$ Purchase Intention $\quad 16.635 \quad 0,000 \quad$ H7: Significantly Positive

The results of the $\mathrm{H} 1 \mathrm{t}$-statistical test can be concluded to be significantly positive because it has fulfilled the requirements for a $\mathrm{P}$ value of less than $0.05(<0.05)$ and a $\mathrm{T}$-statistical value greater than 1.96 . The results of this test are consistent with previous research by Hsu and Lin (2016); Gan and Wang (2017); Yu et al. (2013); Kesari and Atulkar (2016) and Lee and Wu (2017), wherein their research also said that hedonic shopping value has a significant effect on web satisfaction. The results of the $\mathrm{H} 2$ test can be concluded to be significantly positive because it has a $\mathrm{p}$-value of less than 0.05 , the $\mathrm{t}$ statistic value is more significant than 1.96, the results of this test are consistent with previous research Hsu and Lin, (2016); Gan and Wang, (2017); Yu et al., (2013); Lee and Wu, (2017); Kesari and Atulkar, (2016) because their research results also prove that utilitarian shopping value has a significant effect on web satisfaction. H3 can be concluded to be significantly positive because it has fulfilled the requirements. The results of the H3 test are consistent with previous research, Cyr and Head (2013); Wong et al., (2016); Wang et al., (2014); and Ladhari and Leclerc (2013), but these results contradict the research of Ahmad et al., (2017) because the results of their research show that there is no influence between the effectiveness of the information contained on web satisfaction. The results of the $\mathrm{H} 4$ test prove that the hedonic shopping value on online satisfaction as a mediating variable has a significant positive effect on purchase intention because it has fulfilled the requirements that the Pvalue value is smaller than $0.05(<0.05)$. The T-statistics value is greater than 1,96 . The results of this test are consistent with previous research by Gan and Wang (2017) and Hsu and Lin (2016). Their research also said that hedonic shopping value significantly affects Purchase Intention through Web Satisfaction as a mediating variable. The results of the H5 test can be concluded that the utilitarian shopping value has a significant positive effect on purchase intention with web satisfaction as a mediating variable because it has a p-value of less than 0.05 , T-statistical value greater than 1.96. The results of this test are consistent with previous research conducted by Gan and Wang (2017) and Hsu and Lin (2016) because their results also prove that utilitarian shopping value has a significant effect on web satisfaction. The results of the H6 test show that the effectiveness of information content can be concluded to have a clear positive impact on purchase intention with web satisfaction as a mediating variable because it has fulfilled the requirements by having a p-value of 0.000 , smaller than 0.05 at-value greater than 1.96 . The results of this test are consistent with previous research by researcher Wong et al. (2016) because their research results show an influence between the effectivity of information content on purchase intention and web satisfaction as a mediating variable. The results of the $\mathrm{H} 7$ test the effect of web satisfaction on purchase intention is proven to have an impact. The results of this study are consistent with previous research by Hsu and Lin (2016); Cao et al. (2018); Gan and Wang (2017); Papagiannidis et al. (2017); Hsu et al. (2012) because in their research, they concluded that web satisfaction has a significant effect on purchase intention.

\section{Conclusion}

This study was collected from 350 respondent data. The results showed that hedonic shopping value, utilitarian shopping value, and the effectiveness of information content could affect web satisfaction and ultimately affect purchase intention. Besides that, web satisfaction can also mediate the effect of hedonic shopping value, utilitarian shopping value, and the effectiveness of information content on purchase intention.

\section{References}

Ahmad, A., Rahman, O., \& Khan, M. N. (2017). Exploring the role of website quality and hedonism in the formation of e-satisfaction and e-loyalty. Journal of Research in Interactive Marketing, 11(3), $246-267$. https:// doi.org/ 10.1108/jrim-04-2017-0022

Apa Itu Milenial, Generasi yang Andalkan Media Sosial, Internet, Gadget hingga Google Search. (2019). Retrieved from https://bangka.tribunnews.com 2019-03-02 apa-itu-milenial-generasi-yang-andalkanmedia-sosial-internet-gadget-hingga-google-search

Bohang Kartina, F. (2018). Berapa Jumlah Pengguna Internet Indonesia? Kompas. Retrievedfromhttps://tekno.kompas.com/read/2018/02/22/16453177/berapa-jumlah-pengguna-internetindonesia?

Chang, K., Kuo, N., Hsu, C., \& Cheng, Y. (2014). The Impact of Website Quality and Perceived Trust on Customer Purchase Intention in the Hotel Sector: Website Brand and Perceived Value as Moderators. 5(4). https:// doi.org/ 10.7763/IJIMT.2014.V5.523

Chen, J. V., Rungruengsamrit, D., Rajkumar, T. M., \& Yen, D. C. (2013). The success of electronic commerce Web sites: A comparative study in two countries. Information and Management, 50(6), 344355. https://doi.org/10.1016/j.im.2013.02.007

Cyr, D., \& Head, M. (2013). Website design in an international context: The role of gender in masculine versus feminine oriented countries. Computers in Human Behavior, 29(4), 1358-1367. https://doi.org/10.1016/j.chb.2013.01.050

Dirga Cahya, K. (2018). Bagaimana Generasi Milenial Berbelanja Online? Kompas.Retrieved from https:// lifestyle.kompas.com/read/2018/11/26 
Eknomi, P. (2018). Ternyata Ini 5 Alasan Millenial Gemar Belanja Online, Enggak Heran Deh! Portal Berita Ekonomi. Retrieved from Ternyata Ini 5 Alasan Millenial Gemar Belanja Online, Enggak Heran Deh!

Elmashhara, M. G., \& Soares, A. M. (2019). The impact of entertainment and social interaction with salespeople on mall shopper satisfaction: The mediating role of emotional states. International Journal of Retail and Distribution Management. https://doi.org/10.1108/IJRDM-06-2018-0112

Gan Chunmei, \& Wang Weijun. (2017). The influence of perceived value on purchase intention in social commerce context. Internet Research, 27(4), 772-785. https://doi.org/10.1108/IntR-06-2016-0164

Gorrell, G., Ford, N., Madden, A., Holdridge, P., \& Eaglestone, B. (2011). Countering method bias in questionnaire-based user studies. Journal of Documentation, 67(3),507-524. https://doi.org/10.1108/00220411111124569

Hair, J. F., Ringle, C. M., Sarstedt, M., Hair, J. F., Ringle, C. M., \& Sarstedt, M. (2014). PLS-SEM : Indeed a Silver Bullet PLS-SEM : Indeed a Silver Bullet. (January 2015), 37-41. https://doi.org/10.2753/MTP1069-6679190202

Ho, C., \& Lee, P.-C. (2016). Article information: Agency Theory, 1-55. https://doi.org/http://dx.doi.org/10.1108/MRR-09-2015-0216

Hong, P. (2018). Post-purchase shipping and customer service experiences in online shopping and their impact on customer satisfaction An empirical study with comparison. https:// doi.org/10.1108/APJML04-2017-0071

Hsu, C., Chang, K., \& Chen, M. (2012). purchase intention : perceived playfulness and perceived flow as mediators. (313), 549-570. https:// doi.org/10.1007/s10257-011-0181-5

Hsu, C. L., \& Lin, J. C. C. (2016). Effect of perceived value and social influences on mobile app stickiness and in-app purchase intention. Technological Forecasting and Social Change, 108, $42-53$. https://doi.org/10.1016/j.techfore.2016.04.012

$\mathrm{Hu}$, X. (2015). Effectiveness of information technology in reducing corruption in China A validation of the DeLone and McLean information systems success model. Electronic Library, 33(1), 52-64. https://doi.org/10.1108/el-11-2012-0148

IMR 2019: Begini Kebiasaan Millennial saat Belanja Online. (n.d.). Idntimes. Retrievedfromhttps:// www.idntimes.com/tech/trend/bayu/survei-ims-2019-kebiasaan-millennial-saat-belanja-onlineims2019/full

Indah Budiati, SST, M. S., Dr. Yuni Susianto, S.Si, M. S., Dr. Windhiarso Ponco Adi P, S.Si, M. E., Sofaria Ayuni, S.Si, M., Henri Asri Reagan, SST, M. S., Putri Larasaty, S., ... Valent Gigih Saputri, S. (2018). Profil Generasi Milenial Indonesia (CKementerianPemberdayaan Perempuan dan Perlindungan Anak, ed.).

Jateng, T. (2018). UMK Batam 2019, Daftar Lengkap UMK di Kepri (Kepulauan Riau) dari Tertinggi hingga Terendah Artikel ini telah tayang di Tribunjateng.com dengan judul UMK Batam 2019, Daftar Lengkap UMK di Kepri (Kepulauan Riau) dari Tertinggi hingga Terendah, https://jate. Tribu Jateng.Com.

Jatmiko, leo dwi. (2019). Survei APJII: Shopee Aplikasi Belanja Online Paling Populer.Ekonomibisnis.Com. Retrievedfromhttps:// ekonomi.bisnis.com/read/20190604/12/930714

Jeko. (2018). Pengguna Internet Melonjak, Kemkominfo Ngebut Pembangunan Broadband. Retrieved from https:// www.liputan6.com/ tekno/read/3303867

Kesari, B., \& Atulkar, S. (2016). Satisfaction of mall shoppers: A study on perceived utilitarian and hedonic shopping values. Journal of Retailing and Consumer Services, 31, $22-31$. https://doi.org/10.1016/j.jretconser.2016.03.005

Kim, G. Y., \& Li, G. (2009). Customer satisfaction with and loyalty towards online travel products:15(4), 825-846.

Ladhari, R., \& Leclerc, A. (2013). Building loyalty with online financial services customers: Is there a gender difference? Journal of Retailing and Consumer Services, 20(6), 560-569. https:// doi.org/10.1016/j.jretconser.2013.07.005

Latan, H., \& Noonan, R. (2017). Partial Least Squares Path Modeling.

Leavy, P. (2017). Quantitave, Qualitative, Mixed Methods, Arts-Based, and Community-Based Participatory Research Approaches.

Lee, C.-H., \& Wu, J. J. (2017). Consumer online flow experience. Industrial Management \& Data Systems, 117(10), 2452-2467. https://doi.org/10.1108/imds-11-2016-0500

Lui, J., North, Mi., \& Li, C. (2016). Relationship building through reputation and tribalism on company Facebook pages: A uses and gratifications approach. Qualitative Research: Theory, Method, and Practices, 3rd Edition, 18, 405-426. https://doi.org/10.1108/10662240810897817

Mengenal E-commerce dan Jenisnya di Indonesia. (n.d.). Retrieved from https://rendingbisnis.com/index.php/e-commerce-sharing/25-mengenal-e-commerce-dan-jenisnya-diindonesia

Mengenal Generasi Milenial. (2018). Koran Sindo. Retrieved from https://lifestyle.sindonews.com/read/1031568/152/mengenal-generasi-millenial-1439256942

Muchtar, J. (2018). Millennials Dominate Indonesia's Online Shopping Scene. Jakartaglobe. Retrieved from Millennials Dominate Indonesia’s Online Shopping Scene 
New, B. (2017). Mitos Merantau ke BATAM, Bila Anda Tiba Anda Menyesal?Batamnews.Co.Id. Retrievedfromhttps://www.batamnews.co.id/berita-23790-mitos-merantau-ke-batam-bila-anda-tiba-andamenyesal.html

Nugroho, H., W.Ekoputri, A., \& Halim, T. (2017). The Urban Middle-Class Milenials Indonesia : Financial and Online Behavior.

Papagiannidis, S., Pantano, E., See-To, E. W. K., Dennis, C., \& Bourlakis, M. (2017). Information Technology \&amp; People To immerse or not? Experimenting with two virtual retail environments Article information. Technology \& People, 30(1), 163-188.

Pos, B. (2019). Batam Surga Bagi Pencari Kerja. Batampos.Co.Id. Retrieved from https://batampos.co.id/2019/06/12/kota-batam-surga-bagi-para-pencari-kerja/

Prashar, S., Vijay, T. S., \& Parsad, C. (2017). Effects of Online Shopping Values and Website Cues on Purchase Behavior: A Study Using S-O-R Framework. 42(1), 1-18. https:/ /doi.org/ 10.1177/ 0256090916686681

Ramadhan, B. (2018). Inilah Perkembangan Digital Indonesia Tahun 2018. Goodnewsfromindonesia.https://www.goodnewsfromindonesia.id/2018/02/06/inilah-perkembangandigital-indonesia-tahun-2018

Triantafillidou, A., Siomkos, G., Papafilippaki, E., \& Triantafillidou, A. (2017). The effects of retail store characteristics on the in-store leisure shopping experience. https:/ /doi.org/ 10.1108/IJRDM-07-20160121

Wang, Y. S., Li, H. T., Li, C. R., \& Wang, C. (2014). A model for assessing blog-based learning systems success. Online Information Review, 38(7), 969-990. https://doi.org/10.1108/OIR-04-2014-0097

Wong, M., Wong, S., \& Ke, G. (2016). E-government adoption and user's satisfaction: an empirical investigation. Asia Pacific Journal of Marketing and Logistics, 1-55. https:// doi.org/http:// dx.doi.org/10.1108/MRR-09-2015-0216

Yu, J., Zo, H., Choi, M. K., \& Ciganek, A. P. (2013). User acceptance of location-based social networking services: An extended perspective of perceived value. Online Information Review, 37(5), 711-730. https:/ /doi.org/ 10.1108/OIR-12-2011-0202

Yu, W., Ramanathan, R., Wang, X., \& Yang, J. (2017). Industrial Management \& Data Systems Article information : Paper type Research paper. 